\title{
Science and Technology to Advance Regional Security in the Middle East and Central Asia
}

A.F.B. Tompson, J.H. Richardson, R.C. Ragaini, R.B. Knapp, N. Rosenberg, D.K. Smith, and D.Y. Ball

This article was submitted to The International Seminar on Nuclear War and Planetary Emergencies, Erice, Italy, August 18-26, 2002

Lawrence

October 9, 2002

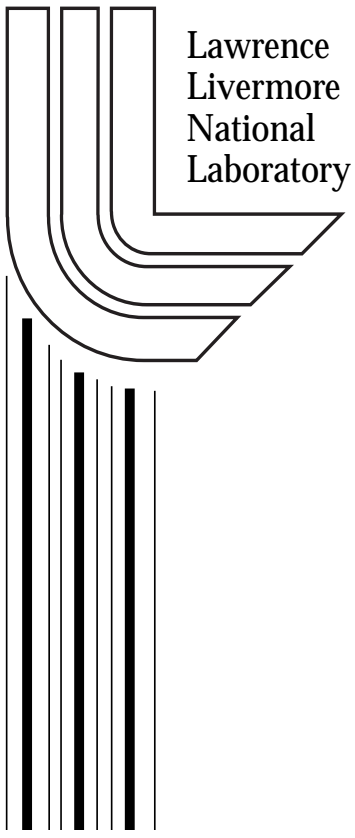




\section{DISCLAIMER}

This document was prepared as an account of work sponsored by an agency of the United States Government. Neither the United States Government nor the University of California nor any of their employees, makes any warranty, express or implied, or assumes any legal liability or responsibility for the accuracy, completeness, or usefulness of any information, apparatus, product, or process disclosed, or represents that its use would not infringe privately owned rights. Reference herein to any specific commercial product, process, or service by trade name, trademark, manufacturer, or otherwise, does not necessarily constitute or imply its endorsement, recommendation, or favoring by the United States Government or the University of California. The views and opinions of authors expressed herein do not necessarily state or reflect those of the United States Government or the University of California, and shall not be used for advertising or product endorsement purposes.

This is a preprint of a paper intended for publication in a journal or proceedings. Since changes may be made before publication, this preprint is made available with the understanding that it will not be cited or reproduced without the permission of the author.

This report has been reproduced directly from the best available copy.

Available electronically at http://www.doc.gov/bridge

Available for a processing fee to U.S. Department of Energy

And its contractors in paper from

U.S. Department of Energy

Office of Scientific and Technical Information

P.O. Box 62

Oak Ridge, TN 37831-0062

Telephone: (865) 576-8401

Facsimile: (865) 576-5728

E-mail: reports@adonis.osti.gov

Available for the sale to the public from

U.S. Department of Commerce

National Technical Information Service

5285 Port Royal Road

Springfield, VA 22161

Telephone: (800) 553-6847

Facsimile: (703) 605-6900

E-mail: orders@ntis.fedworld.gov

Online ordering: http://www.ntis.gov/ordering.htm

\section{OR}

Lawrence Livermore National Laboratory

Technical Information Department's Digital Library

http://www.llnl.gov/tid/Library.html 


\title{
SCIENCE AND TECHNOLOGY TO ADVANCE REGIONAL SECURITY IN THE MIDDLE EAST AND CENTRAL ASIA
}

\author{
ANDREW F. B. TOMPSON, JEFFERY H. RICHARDSON, RICHARD C. RAGAINI, \\ RICHARD B. KNAPP, NINA D. ROSENBERG, DAVID K. SMITH, AND DEBORAH \\ Y. BALL \\ Lawrence Livermore National Laboratory, Livermore, CA 94550 USA \\ INTRODUCTION
}

This paper is concerned with the promotion and advancement of regional security in the Middle East and Central Asia through the development of bilateral and multilateral cooperation on targeted scientific and technical projects. It is widely recognized that increasing tensions and instability in many parts of the world emphasize - or reemphasize - a need to seek and promote regional security in these areas. At the Lawrence Livermore National Laboratory (LLNL), a national security research facility operated for the US Department of Energy, we are pursuing an effort to use science and technology as a "low risk" means of engagement in regions of strategic importance to the United States. In particular, we are developing collaborations and cooperative projects among (and between) national laboratory scientists in the US and our various counterparts in the countries of interest.

\section{HOW CAN SCIENCE AND TECHNOLOGY IMPROVE REGIONAL SECURITY?}

First and foremost, scientific cooperation is often recognized as a means of mitigating conflict $^{1}$. Scientific collaborations can address meaningful problems that could otherwise lead to destabilizing tensions in some regions of the world. Because science and technology have become the dominating factor in the global economy, they can either close or exacerbate the economic gap between rich and poor countries. Science and technology use a common language that transcends state and cultural boundaries, offer a positive and benign process for engaging governmental and civilian organizations, and involve participation from military, academic, ministerial, private organizations and other important stakeholders. As a result, scientific cooperation may be come an important facilitating factor among nations in conflict. Specific and targeted science and technology projects can make a tangible difference by improving the indigenous capacity and standard of living and providing tools to respond to real and critical regional problems. 
They are a powerful process for collaboration and can lead to collateral economic, educational, and public health benefits.

\section{Our Approach}

We are using a three-step process to foster the development of scientific collaboration and cooperation in two areas of the world important to the United States national interest - the Middle East and Central Asia.

Over the past five years, for example, we have (i) conducted several fact-finding technical missions to these regions in order to develop scientific contacts, meet government officials, visit important non-governmental organizations and academic institutions, and otherwise gain a sense for important technical problems affecting the regions, especially those that are congruous with our own technical capabilities.

Following these visits, we have (ii) developed a prioritized group of projects through a series of regional workshops involving American and regional scientists. In general, the projects we develop are fully collaborative, bilateral or multilateral in nature, and are, of course, science and technology based. These projects must provide an opportunity for engagement in the region of interest, for addressing real problems in the regions, and, if possible, also promote the improved education and welfare of the local population.

Ultimately, (iii) funding for the projects is sought, both for participants in the regions as well as for the US counterparts. It is important to emphasize that we are not developing a "blind" or unidirectional program of aid and grants, but, rather, establishing real and lasting cooperative ventures on a bilateral or multilateral basis. Although many projects may involve small amounts of funding or require short turn around times, the scientific relationships created in this process can be continuing and lead to more involved interactions in the future.

\section{The Middle East and Central Asia}

In the Middle East, for example, the need for engagement among various parties (Israel, The Palestinian Authority, Jordan, and Syria, among others) has long been recognized as an important aspect of the peace process and overall progress toward regional security. More recently, the growth of international terrorism in Central Asia and the potential trafficking of nuclear materials and drugs is being recognized as a threat to the emerging economies in the region - e.g., the development of important energy resources. This has revealed a stronger need to promote broad-based regional cooperation in a number of areas, especially with respect to the resolution of the disposition of shared water resources and the elimination of regional environmental threats ${ }^{2}$. 


\section{Cooperative Project Subject Areas}

As a result of our fact-finding trips and regional workshops, we have pursued a number of science and technology collaborations in the area of environmental threats in both the Middle East and Central Asia.

The environment provides an obvious topic for regional engagement, as most environmental issues are either intrinsically regional (e.g., transboundary river basins, groundwater aquifer management, air pollution, etc.) or are replicated on a regional basis (e.g., water salinity problems, industrial pollution of surface and groundwater, Soviet era radioactive material legacies, etc.). The US Central Combatant Command (US Military), whose are of responsibility includes Central Asia and portions of the Middle East, has recognized and endorsed this concept, making "environmental security" a key part of its engagement strategy ${ }^{3}$. Although there has been considerable debate as to whether environmental degradation or regional competition for scarce water resources can lead directly to violent conflict, there is general agreement that these factors exacerbate existing conflicts and can be regarded as a vehicle to stimulate broader regional cooperation $^{4-6}$.

Engagement focused on environmental issues (e.g., water quality and quantity) includes characterization and simulation to first define environmental threats, rapidly engineered upgrades to proactively manage environmental issues affecting public health, the economy and state stability, and regional technical and government networks to coordinate solutions. Coordinated emergency response planning and exercises addressing potential environmental disasters (e.g., floods, earthquakes, and terrorist attacks) promote regional cooperation and develop indigenous capacity and infrastructure. These are meaningful issues that can be translated in to substantive actions on the ground in these countries. In the following sections, a summary of some of the projects underway or under consideration by our organization will be provided.

\section{MIDDLE EAST}

Experiential Education in Groundwater Hydrology: Bridging the Technical - Policy Populace Gap

This is a small bilateral project being conducted between LLNL and several partner organizations in Jordan under the sponsorship of the Bureau of Educational and Cultural Affairs of the US Department of State. The project involves two principal activities that are being coordinated with the Jordan University of Science and Technology (JUST), the Royal Society for the Conservation of Nature (RSCN) and the Jordanian Ministry of Water and Irrigation (MWI).

The first part of the project involves a series of educational activities with all partners to educate primary-aged children, laypersons, academic, government, other technical professionals, and farming communities on basic groundwater issues - its production, depletion, movement, pollution, and recycling as part of the hydrologic cycle. This is 
particularly relevant in Jordan where water shortages are acute, reliance on renewable groundwater is significant, and, as in most places, the general awareness or recognition of groundwater as an important resource is limited. The lack of reliable water supplies in Jordan and the region as a whole can threaten the kinds of economic development that are often seen as necessary ingredients for long-term peace and stability in the region.

As part of this activity, we are constructing a series of two-dimensional physical groundwater models for use by RSCN, JUST, and MWI. RSCN, in particular, will utilize these models in their Azraq Wetlands Visitors Center for demonstration and educational purposes. Although such physical models may be used for education of school children (Figure 1), they will also be used and replicated in the university environment at JUST, as well as for public awareness and outreach purposes at the MWI.

The Azraq wetlands are located in the middle of the Azraq basin in central Jordan (Figure 2) and exist now only because of a small restoration effort that has been implemented by RSCN. What exists now is only a remnant of a vast and thriving oasis that existed in this location for thousands of years as a resting point for animals, waterfowl, and desert travelers alike. The death of the wetlands was created by largescale, unsustainable production of groundwater from the Azraq aquifer - underlying the oasis - and the subsequent lowering of regional groundwater levels. The Azraq aquifer extends from Syria to Saudi Arabia and has been largely used to provide water to the capital city of Amman. Aquifer management is complicated by numerous illegal and undocumented wells, complicated geology, and an inability to effectively understand or predict the nature of increasing salinity in much of the aquifer's water.

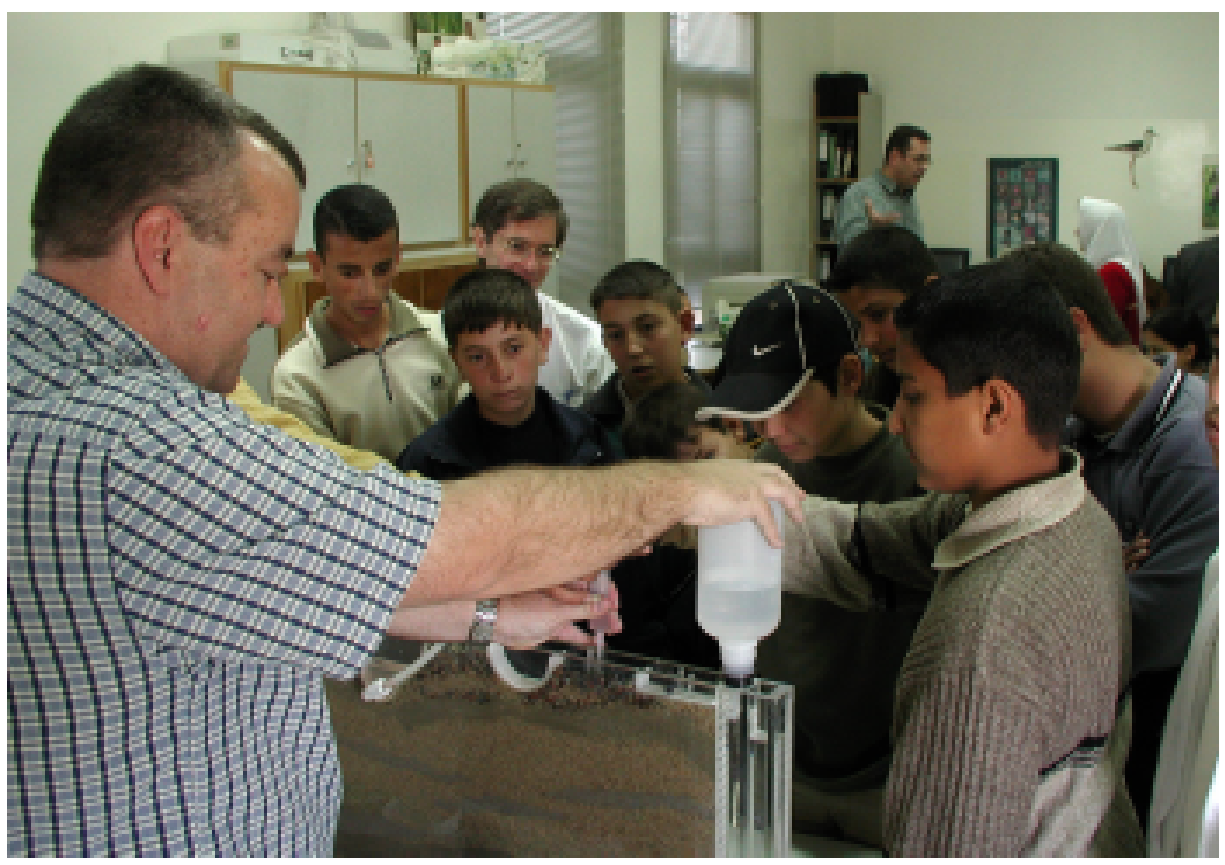

Figure1: Demonstration of physical model to schoolchildren at the Azraq Wetlands Visitors Center in Jordan. 


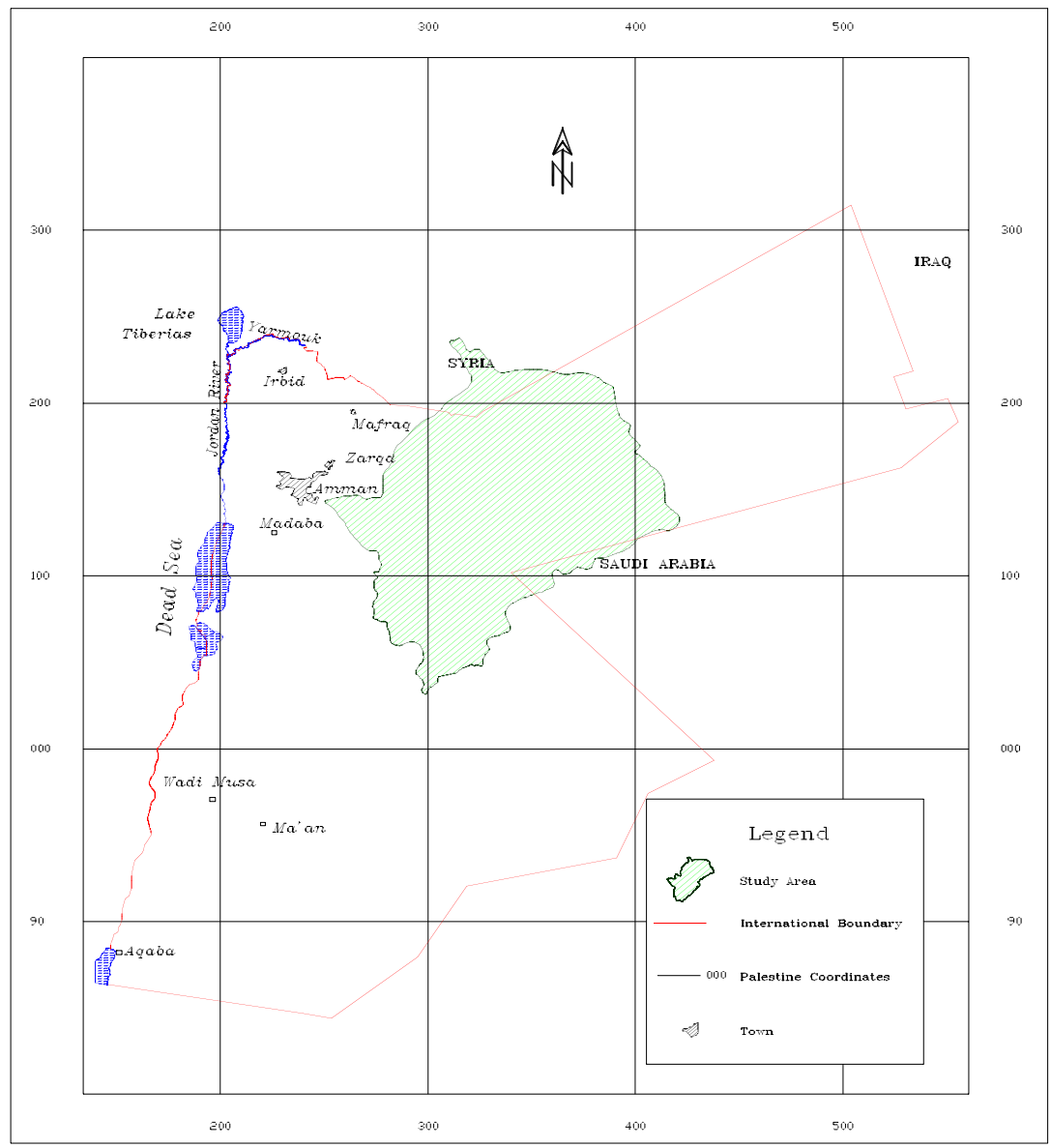

Figure 2: Location of the Azraq groundwater basin in Jordan.

A second part of this project involves technical exchanges, primarily with JUST and MWI, regarding the use of new LLNL computer-based groundwater simulation models. In this part of the effort, we are developing an application of an LLNL-developed model to the Azraq aquifer (Figure 2). The model is intended to provide an improved basis for aquifer management in much of Jordan.

\section{$\underline{\text { Solar Powered Desalination and Pumping Unit for Brackish Water }}$}

In many parts of the Middle East, including both Jordan and the Palestinian territories, there are numerous small villages populated by indigenous nomadic or semi-nomadic people that rely on remote - and often brackish - sources of groundwater for human and livestock consumption. The relatively high salinity levels in this kind of water $(\sim 3000-$ 8000 parts per million) are not acceptable over the long-term from human health perspectives.

The overall technical objective of this type of project is to develop expandable, portable, and remotely powered systems to supply desalinated water to small 
communities (less than 2000 people) and their associated livestock. Such a system should be able to deliver at least $100-200 \mathrm{~m}^{3} /$ day, be powered by renewable (photovoltaic) energy sources and be portable enough to be transported in a small truck for nearby communities.

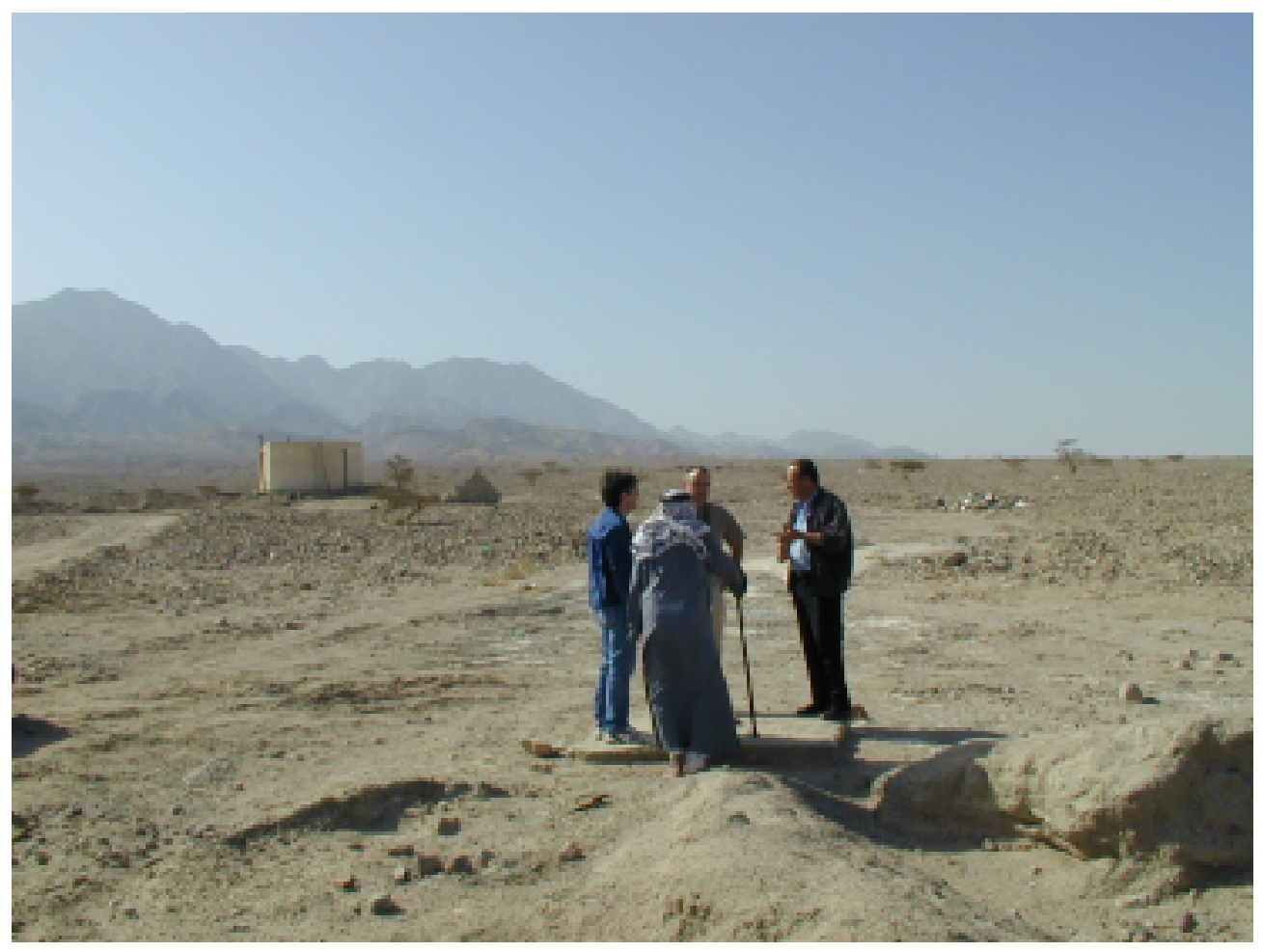

Figure 3: Visit to Qatar, Jordan on April 12, 2002. Project participants confer with village leader (rear facing, front) on top of a new $50 \mathrm{~m}$-deep well from which a new solar-powered desalination unit will draw brackish groundwater. Treated water will be delivered to the recently completed cistern for the village, several meters in the background.

A prototype effort has recently been initiated by the National Renewable Energy Laboratory (NREL) of the US Department of Energy, in collaboration with the Middle East Regional Cooperation program of the US Agency for International Development, the Jordanian Ministry of Water and Irrigation (MWI), and the Royal Scientific Society of Jordan. In this project, a portable, solar-powered desalination unit developed for the US military was procured and is being shipped to the small village of Qatar, $35 \mathrm{~km}$ north of Aqaba, in southern Jordan (Figures 2 and 3). Although the village has access to brackish groundwater in a series of newly developed wells, it relies nonetheless on freshwater delivered by truck each week from Aqaba. At this time, additional units are being considered for other locations in Jordan and in the neighboring Palestinian territories. 


\section{CENTRAL ASIA}

\section{$\underline{\text { Radionuclide Contamination at the Ulba Metallurgical plant }}$}

The Ulba Metallurgical Plant (UMP) is situated in Ust-Kamenogorsk, in eastern Kazakhstan. In its 50-year history of continual operation, the facility has dominated the industrial base of the city through the production of processed uranium and specialty metals such as beryllium, tantalum, and niobium. By the mid 1950s, commercial processing of beryl ores at UMP allowed the large-scale production of high-purity beryllium oxides, alloys, and ceramics for a wide variety of atomic defense (including nuclear weapon) and industrial applications. Since this time, tantalum and niobium have also been regularly produced as metal powders and ceramics. Uranium production also began in the 1950s and evolved toward the production of low-enriched uranium during a period when the former Soviet Union was developing large-scale applications of nuclear power. UMP produced significant quantities of propulsion fuel for the nuclear navy fleet of the Soviet Union and, subsequently, Russia. From 1976 and continuing to the present, the plant has produced fuel pellets for nuclear power plants on a commercial scale.

Accompanying the production of these metals is a significant amount of liquid waste residues, which have been, and continue to be generated and disposed of in several retention basins adjoining the facility (Figure 4). The engineered containment barrier underlying one of the basins has failed and allowed accumulated liquid wastes in the basin to percolate into groundwater and pose a significant threat to nearby potable groundwater supplies in Ust-Kamenogorsk. Although this basin is no longer used, precipitated and other solid forms of the wastes remain in the basin, are entrained in accumulated rainfall and snowmelt, and continue to be discharged into the local groundwater as a persistent and lasting source of contamination.

The overall objective of the project - which is still in its planning stages - is to develop a conceptual and numerical model of groundwater flow and chemical transport that can be used to analyze the migration of contamination in the water supply aquifers underlying the UMP disposal basins. The model will be applied ultimately as a means to protect local groundwater quality by facilitating the remediation of existing contamination and the stabilization and control of contaminant discharges from liquid waste ponds at the plant. In addition, the model will also be used, in its initial stages of development, to determine the need for, and guide the acquisition of additional characterization and model calibration data, and later in the design of groundwater monitoring strategies. The importance of this project is underscored by the importance of the UMP plant itself as a productive economic enterprise for all of Kazakhstan. 


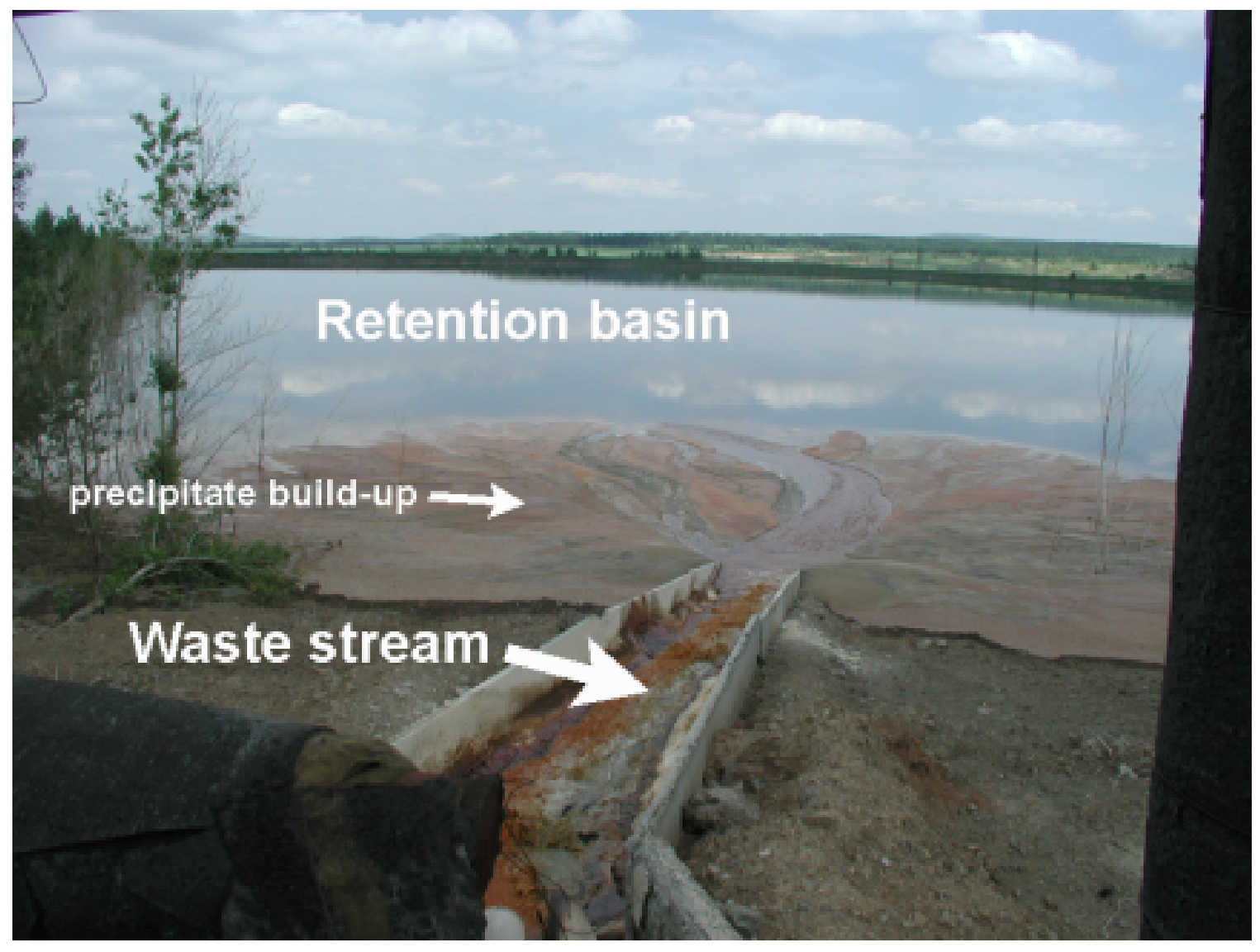

Figure 4. One of three actively used evaporative retention basins at the UMP plant in Ust-Kamenogorsk, Kazakhstan, showing existing mixed waste discharges and the build up of precipitate wastes.

\section{Assessment of Radionuclide Migration in Groundwater at the Semipalatinsk Test Site}

The Semipalatinsk Test Site (STS) in northern Kazakhstan was one of several areas used for the testing of nuclear weapons by the Former Soviet Union. Of a total of 456 nuclear tests carried out at STS, 340 were conducted in underground shafts or tunnels, 30 others were exploded on the ground surface, and the remaining 86 were detonated in the atmosphere. Within the STS, underground testing occurred within tunnels bored into the Degelen Mountain complex (209 tests) and within vertical shafts at the Balapan (109 tests) and Murzhik (26 tests) areas (Figure 5).

Although there has been considerable interest in the distribution and impacts of residual radionuclides produced by the atmospheric testing (e.g., radiologic fallout and dose), there has been far less scrutiny of the fate of residual radionuclides from underground tests and, in particular, their potential to contaminate and migrate in groundwater and other drinking water supplies in the STS area ${ }^{7}$. Existing efforts have largely concentrated on monitoring programs in wells, rivers, and precipitation discharges from tunnels, and have not focused on examining the future potential for 
additional contamination or understanding more completely the interconnected processes that lead to such contamination.

The overarching rationale for the project - which is still in its planning stages - is based upon the need for preserving the integrity and quality of groundwater resources in Kazakhstan and, in particular, for understanding the nature and magnitude of specific threats to these resources posed by the legacy of underground nuclear testing. Based on the hydrologic setting and nature of the nuclear tests conducted, our Kazakhstani colleagues have identified the Balapan site within the STS for the development of a hydrologic flow model and the smaller Zarechny site located within Balapan for the development of the initial radionuclide transport model (Figure 6). The models will be used to study the release of radionuclides from one or more underground nuclear tests conducted below the water table and to examine the potential for their eventual migration in groundwater away from the testing areas.

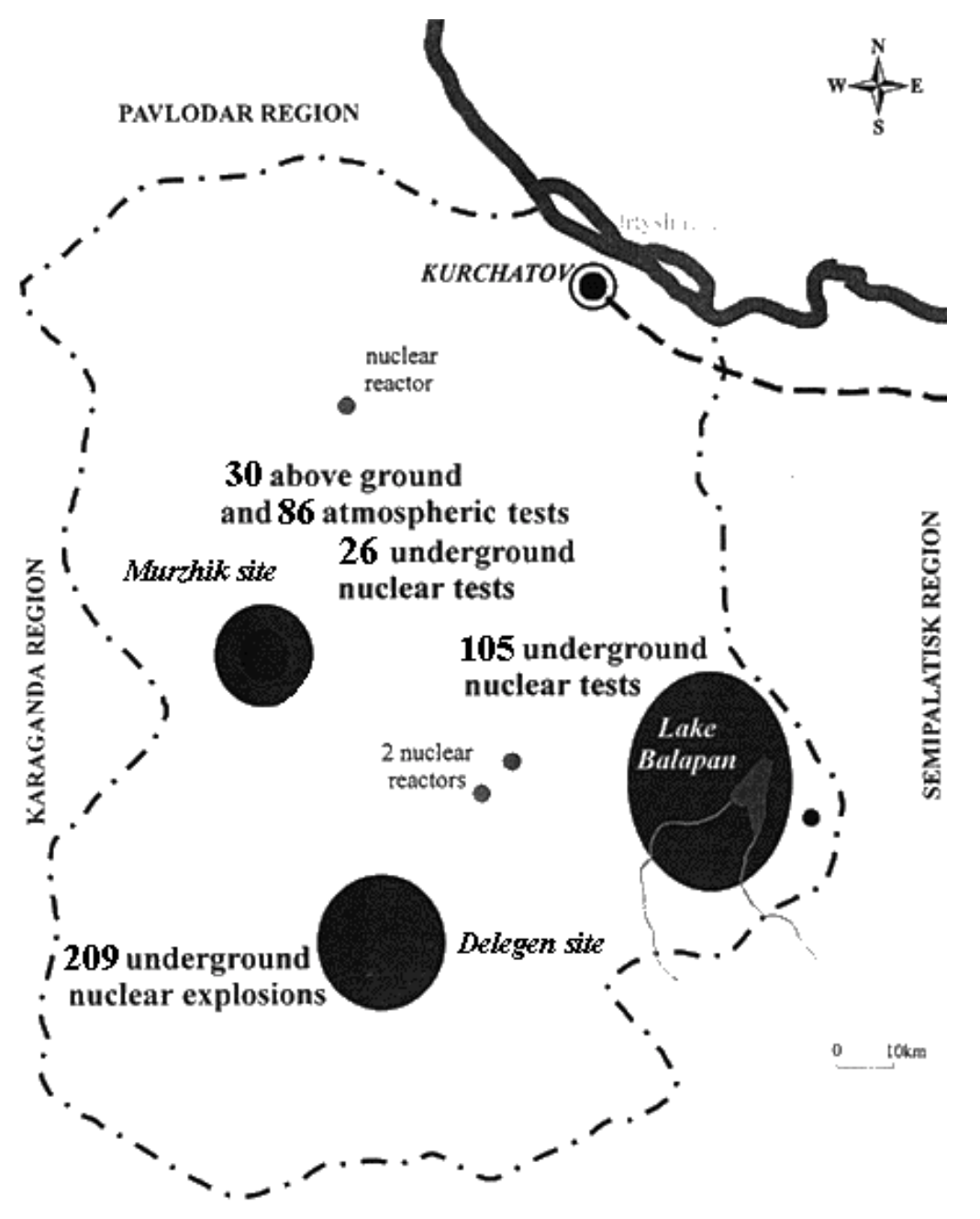

Figure 5: Schematic of the Semipalatinsk Test Site in Northern Kazakhstan with the Balapan area highlighted. 
Specifically, the overall project will emphasize:

- The nature of radionuclide releases from underground nuclear tests into groundwater, and their subsequent migration in groundwater, to be better quantified and understood;

- Better and more informed perspectives on these problems to be developed such that existing monitoring data may be better understood or such that future monitoring operations may be better planned;

- Improved understanding of the risk posed from groundwater contaminated with test-related radionuclides, better management practice for remediation or other reclamation activities, and in general, development of decision-making tools to better evaluate or otherwise modify groundwater use practices in contaminated areas; and

- Similar analyses to be undertaken at other testing areas within the Balapan area or the STS in general (Figures 5 and 6), or to manage other radionuclide contamination problems not associated directly with underground nuclear testing.

and will parallel similar endeavors that have been initiated at the US testing areas at the Nevada Test Site $^{8}$ and at the French testing areas in the South Pacific ${ }^{9}$.

Protecting Yssyk-Köl from Radioactive Contamination and Preserving Kyrgyzstan's Economic Future

This project has been developed to eliminate a significant radioactive threat to Yssyk-Köl in eastern Kyrgyzstan - one of the world's largest mountain lakes - and to preserve what is widely believed to be this country's key economic resource. Central Asia has emerged as an area of extreme strategic interest since 11 September. The war in Afghanistan has accentuated the region's ethnic rivalries, the slow growth of democratic regimes, the collapse of regional economies, and the rise of fundamentalist Islam. Compounding these social and political conditions is an environmental legacy from the Soviet nuclear weapons program - the Kaji-Say radioactive uranium tailings pile - that threatens to destroy assets fundamental to any economic recovery.

The Kaji-Say tailings pile is precariously poised on the banks of a wadi (dry, ephemeral streambed) approximately one kilometer away from Yssyk-Köl (see Figure 7). The tailings pile has a volume of about $150,000 \mathrm{~m}^{3}$ and has been swelled by the continual addition of debris, some of which is radioactively contaminated equipment. Although though the precise contents of this pile are not available, spot exposure readings as high as $800 \mu \mathrm{R} / \mathrm{hr}$ have been recorded; the limiting exposure standard in Europe is $60 \mu \mathrm{R} / \mathrm{hr}$.

The hazard at Kaji-Say is the catastrophic collapse of the uranium tailings pile, its incorporation into a flash flood, and the subsequent transport of radioactive sludge to Yssyk-Köl. Rain storms in this arid climate are infrequent (less than $300 \mathrm{~mm}$ of rain per year) but severe and intense. The position of the pile and its unstable slopes make it wholly susceptible to collapse and transport. 


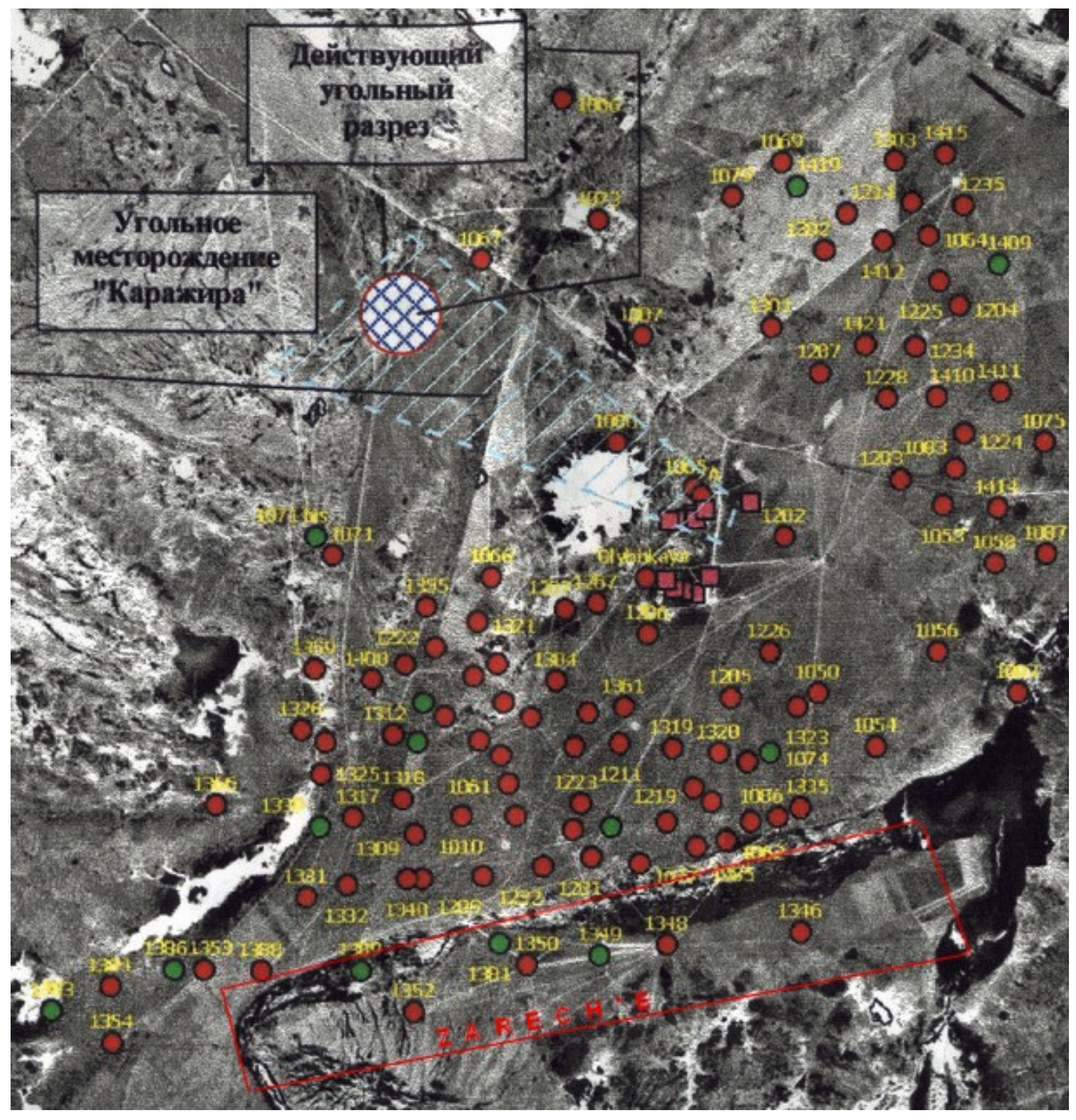

Figure 6: Areal photo of the Balapan area in the Semipalatinsk Test Site in Northern Kazakhstan showing red "military" shafts and green unused boreholes. The smaller Zarechny site is outlined in the bottom (courtesy: S. Subbotin).

This project, recently funded by the US Department of State, will involve

- Relocating uncontained uranium tailings from below an existing retention dam to above the dam,

- Rehabilitating and armoring the existing retention dam to prevent radioactive debris from reaching Ysyk-Köl,

- Conducting erosion control operations at the base of the uranium tailings pile, 
- Repairing the existing tailings cover,

- Installing a specialized fence with appropriate signage

Development of a series of monitoring wells along the axis of the wadi to assess whether (or to what extent) underlying groundwater has been contaminated from uranium leached from the tailings piles.

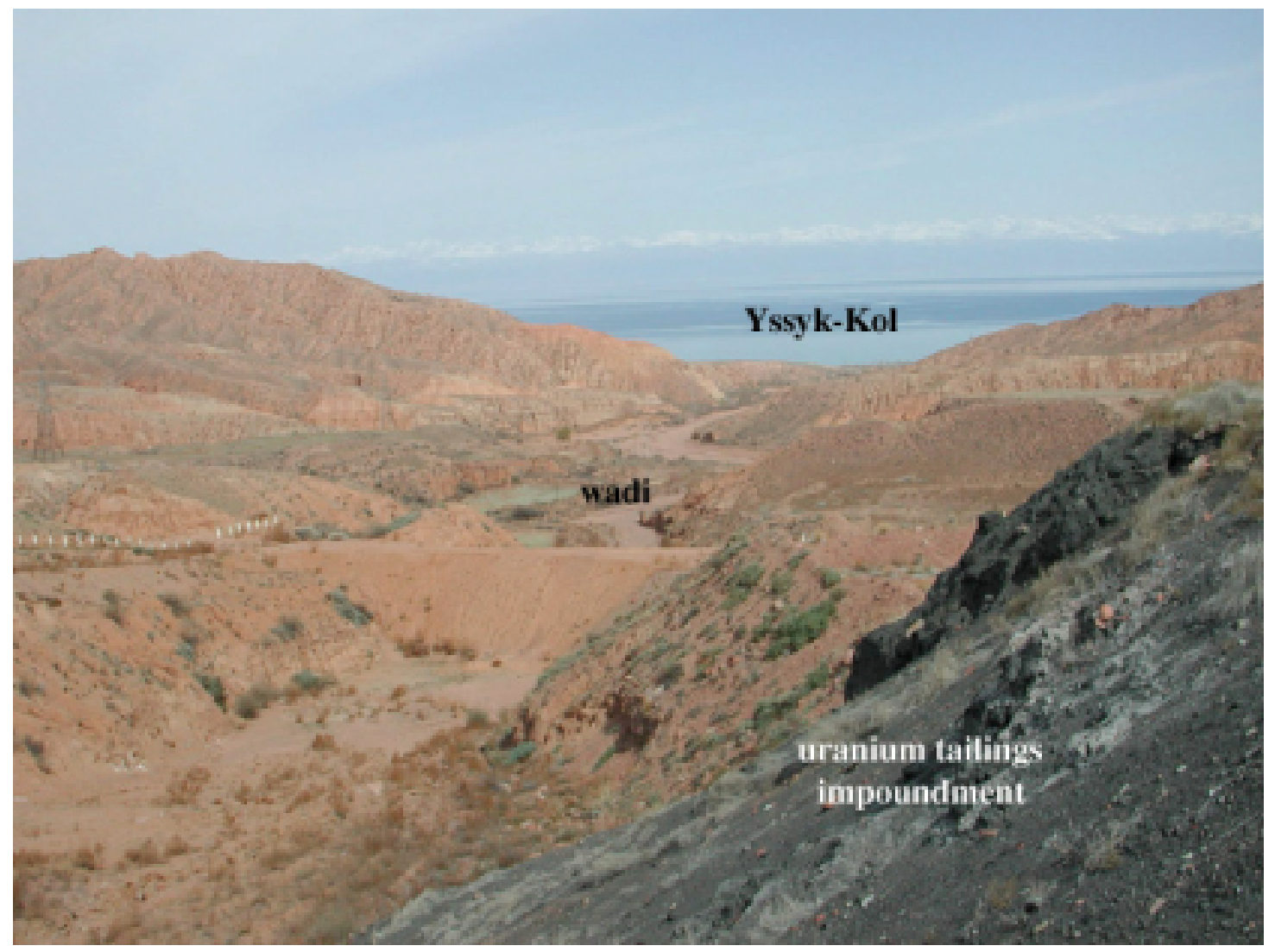

Figure 7. A photograph of the precarious lake-side bank of the Kaji-Say radioactive tailings pile. Looking to the North, Yssyk-Köl is approximately one kilometer away. The snow-capped Tien Shen mountains can be seen in the distance. The dry stream bed (wadi) in the background floods during rainstorms and threatens to sweep the uranium pile downstream into the lake.

Situated at an altitude of 1,620 m, Yssyk-Köl is analogous to Lake Tahoe in the United States, although it has more than 12-times greater surface area $(\sim 6,220 \mathrm{sq} . \mathrm{km})$. It reaches a depth of $702 \mathrm{~m}$, is slightly saline, and is ice-free in winter. No motor craft are allowed on the lake in an effort to preserve its water quality. Yssyk-Köl is well known throughout the Eurasian continent as a popular Soviet-era vacation destination. Collapse of the Soviet Union was accompanied by a collapse in tourism. Any radioactive contamination of Yssyk-Köl would be quickly reported through-out the Eurasian 
continent (and perhaps world) and would jeopardize this as an economic resource for generations.

This project will provide a technological and science-based strategy for mitigating the threat of radionuclide contamination cross the entire region. It is a demonstration project that produces a trained workforce, a sound scientific approach, and the appropriate analytical tools to interpret results.

\section{SUMMARY}

This paper has been concerned with the promotion and advancement of regional security in the Middle East and Central Asia through the development of bilateral and multilateral cooperation on targeted scientific and technical projects, especially those that that focus on the resolution of important regional environmental threats. Although several prototype projects developed by the authors and their regional colleagues have been described, they by no means represent the full spectrum of problems, nor the range of Western organizations involved in collaboration and solution efforts. For example, the US Agency for International Development, through its Middle East Regional Cooperation Program, has developed a significant cooperative program involving the sue and management of groundwater in the West Bank and Gaza ${ }^{10}$. In Central Asia, for example, there are numerous and significant environmental problems surrounding the Caspian and Aral Seas. We are considering several new collaborations on the Caspian Sea, which will complement the work of the Caspian Environment Programme ${ }^{11}$. Several other regional cooperative efforts with European organizations are also being focused on the Aral Sea $^{12,13}$.

\section{ACKNOWLEDGEMENTS}

This work was conducted under the auspices of the U. S. Department of Energy by the University of California, Lawrence Livermore National Laboratory under contract W7405-Eng-48.

\section{REFERENCES}

1. C. de Cerreno, A. L. and A. Keynan, eds. (1998), Scientific Cooperation, State Conflict: The Role of Scientists in Mitigating International Discord, Annals of the New York Academy of Sciences, Vol. 866, NY.

2. IGC (2002), Central Asia: Water and Conflict, ICG Asia Report No. 34, International Crisis Group (http://www.intl-crisis-group.org), Osh/Brussels, May.

3. Hughes, E. L., K. H. Butts, B. F. Griffard, and A. L. Bradshaw, Jr., editors (2001), Responding to Environmental Challenges in Central Asia and the Caspian Basin, Center for Strategic Leadership, U. S. Army War College, PA. 
4. Homer-Dixon, T., (1999), Environment, Scarcity, and Violence, Princeton University Press, Princeton NJ.

5. Wolf, A. T. (1997), International Water Conflict Resolution: Lessons from Comparative Analysis, International Journal of Water Resources Development, $13,3$.

6. McMelis, D. and G. E. Schweitzer (2001), Environmental Security: An Evolving Concept, Environmental Science and Technology, 35(5), 108A

7. IAEA (1998a), Radiological Conditions at the Semipalatinsk Test Site, Kazakhstan: Preliminary Assessment and Recommendations for Further Study, International Atomic Energy Agency, Vienna (STI/PUB/1063).

8. USDOE (1997), Regional groundwater flow and tritium transport modeling and risk assessment of the underground test area, Nevada Test Site, Nevada, U. S.

Department of Energy, Nevada Operations Office, Environmental Restoration Division, Las Vegas, NV (DOE/NV--477).

9. IAEA (1998b), The radiological situation at the atolls of Mururoa and Fangataufa. Technical report, Volume 4. Releases to the biosphere of radionuclides from underground nuclear weapons tests at the atolls. International Atomic Energy Agency, Vienna, Austria (IAEA-MFTR-4).

10. http://www.usaid.gov/wbg/program_water.htm

11. http://www.caspianenvironment.org/

12. http://www.aral.uz/

13. http://www.environmonument.com/Aralsea.htm 